\title{
Review Article \\ Review of Exogenous Economic Indicators Influencing Construction Industry
}

\author{
Richard Oduro Asamoah $\mathbb{D D}^{1}{ }^{1}$ Bernard Kofi Baiden $\mathbb{D D}^{2},{ }^{2}$ Gabriel Nani, ${ }^{2}$ and Ernest Kissi ${ }^{2}$ \\ ${ }^{1}$ CSIR-Building and Road Research Institute, Kumasi, Ghana \\ ${ }^{2}$ Department of Construction Technology and Management, Kwame Nkrumah University of Science and Technology, \\ Kumasi, Ghana \\ Correspondence should be addressed to Richard Oduro Asamoah; richardasamoah760@yahoo.com
}

Received 24 September 2019; Revised 25 October 2019; Accepted 13 November 2019; Published 4 December 2019

Academic Editor: Venu G. M. Annamdas

Copyright (C) 2019 Richard Oduro Asamoah et al. This is an open access article distributed under the Creative Commons Attribution License, which permits unrestricted use, distribution, and reproduction in any medium, provided the original work is properly cited.

\begin{abstract}
Research works into the effect of economic factors on the construction industry are enormous. But finding the core economic factors is limited in the Ghanaian construction industry. In an attempt to address this research gap, this study articulates the aim of identifying exogenous economic factors influencing the construction industry through a qualitative literature review. The study used secondary data collected from over 50 published journals, conference papers, and dissertations on exogenous factors. Fiftynine exogenous factors were identified, and the most prevailing ones were GDP, exchange rate, inflation, interest rate, consumer price index, etc. It also revealed that black market is a factor affecting construction industry in Saudi Arabia. The study contributes to the literature by highlighting generic and specific exogenous factors that should be of concern to players in the construction industry including policy makers in their project planning. This will help to reduce the incidence of high failure rate of construction firms. Again, it establishes the need to further study the real impact of these exogenous factors as well as the strategies to mitigate the influence of exogenous factors on the construction industry as this study was limited to qualitative literature review.
\end{abstract}

\section{Introduction}

Construction firms are generally the bedrock of the industrial development in terms of infrastructure delivery [1]. Apart from the numerous goods and services produced, the industry provides a veritable means of large-scale employment which are usually labour intensive. These firms are also a source of wealth creation and innovation by introducing competitive strategies which set them apart from other firms $[2,3]$. Again firms in the construction industry serve as training grounds for employees' development and rely on the use of local raw materials which generate employment opportunities for the beneficiary communities [2].

Notwithstanding the significant progress in performance of construction firms, the situations in many of developing countries are less to be desired [4-6], particularly industry's ability to sustain profitability and growth and also measures to minimize the impact of exogenous economic factors, as most Small construction firms do not survive within the first five years of establishment $[7,8]$. The reliability and stability of exogenous factors do affect profitability and growth within the construction industry [9]. The study sought to address what are exogenous factors and which of them do influence the construction industry. The purpose of this study is to identify exogenous economic factors influencing the construction industry through a comprehensive literature review. The study will seek to establish exogenous economic factors that are fundamental and require further studies to determine their real impact on the construction industry and also what exogenous factors that policy makers and players in the construction industry should be conscious of. The paper is structured in the background literature, methodological approach through which data were collected. Identification of exogenous factors is discussed in conclusions and recommendations. 
1.1. Definition of Exogenous Variable. Galawe [10] defined exogenous factors as independent factors that are not influenced by other variables in an organization. The macroenvironment contains external factors that can assist or deter the growth of firms. They can also be described as factors that firms do not have managerial control or risk factors which operate outside the business environment, and it is very difficult to predict their occurrence, reliability, and accuracy $[10,11]$. Various authors have classified exogenous factors to include political factors, government support and policies, social, economic and cultural, legal framework, and level of market competition [10-13]. The unstable nature of exogenous economic factors affect the operations of firms in the construction industry specially in developing economies [14].This study focuses on identifying economic variables within the exogenous factors through qualitative literature review and classifies the identified variables into constructs for better understanding. The study defines exogenous factors as macrovariables that are independent and have influence on other related variables and not determined by individual firm.

1.2. Review of Literature on Exogenous Economic Factors Influencing Construction Industry. Bok et al. [15] stated that understanding the concept of exogenous factors helps to appreciate the functioning of a complicated modern economic system, describe how the economy as a whole functions, and how the basis of aggregate demand and supply is determined. In a relation to this, proper management of exogenous economic indicators brings stability in price level and analyses fluctuations in business activities and also suggests policy measures to control inflation and deflation [16-20].

This section of the study seeks to identify exogenous factors that affect the construction industry through the literature review. Honorée et al. [21] assess the impact of economic and cultural variables influencing the demand for skyscrapers. The economic variables identified were zoning regulations, land value, relative rents, taxes and subsidies, GDP growth rate, and real interest rate. Fieldhouse et al. [22] considered housing statistics, real house prices, homeownership rate, real personal consumption expenditures, real personal income, and unemployment rate on government asset purchases as evidenced from postwar United State housing credit policy as factors. Inflation rate and currency exchange rate were the determinants in estimating building project cost in Indonesia [23]. Asie et al. [24] postulated that unemployment rate, GDP, and inflation were the main indicators influencing the determination and predicting of correlation of macroeconomic indicators on credit risk. Zhao et al. [25] identified GDP, capital goods prices, producer price index (PPI), consumer price index (CPI), productivity in the construction industry, labour costs, net migration, employment rate, housing prices, building consents, energy prices, exchange rate, monetary policies, investor confidence, and fiscal policies influencing building development cost in New Zealand. In South Africa, the Construction Industry Development Board and the
Public Works Department [26] identified prices of global commodities, inflation, crude price, exchange rate, and prime rate as the main cost drivers in the construction sector. Kembe and Onoja [27] also identified GDP, public finance, fixed asset, private investment, net export, consumption, external reserve, net savings, and inflation rate, balance of payment, net import, forex rate, and public debt as influential factors. In Malaysia, GDP and bank lending rate were the leading indicators in the relationship between housing finance and macroeconomic variables [28]. Mansur et al. [29] concluded that high interest rate, increase in cost of production, high cost of fuel, and increase in cost of importation were the main causes of price changes. In the development of urban transport development in China, Ling et al. [30] identified per capita, GDP, GDP, industrial added value, agricultural added value, forestry and animal husbandry, fixed asset investment, and total retail sales of social consumer goods as the main economic indicators. After analyzing 26 sub-Saharan countries from 2000-2013, Alagidede and Odei Mensah [31] used population, trade openness, savings, inflation, and lagged growth rate of real GDP per capita as independent variables to assess the construction industry and economic growth in countries sub of the Sahara. Kalu et al. [32] concluded the relationship between the inflationary rates and prices of building materials in the face of Monetary Policy Rate (MPR); the MPR controls price fluctuation in the general economy, but this was not the case for building material prices in Nigeria. Adegbembo and Adeniyi [33] evaluated the effect of inflation, exchange rate, and interest rate on building material prices and recommended the reduction in the real figures of these indicators. Denise et al. [34] established that real GDP, real interest rate, and unemployment rate were influencing prices of housing in the United States of America. According to Çoban et al. [35], the Turkish construction sector is influenced by employment, GDP, balance of payment, and foreign direct investment. In Greek, Panagiotidis and Panagiotis [36] through literature review established GDP income, interest rate, inflation, employment, loans, demography, and taxation as the main indicators for the housing market. Gathuru [37] investigated the effects of inflation, GDP, employment growth, population growth, cost of construction, and percentage of debt financing on value of real estate supply in Kenya from 2009-2013 and concluded that GDP has positive relationship on the supply of real estate in Kenya. Oghenekevw et al. [38] assessed the impact of inflation on construction material prices in Nigeria and concluded that factors such as importation, interest rate, GDP, and political regimes contribute to upward trend in price. Bełej and Cellmer [39] stated that GDP, inflation, prime rate, unemployment, and number of new houses have effects on real estate prices in Poland. In analyzing temporal relationship between highway construction cost and macroeconomic [17], Mohsen postulated that PPI, GDP, GDP-implicit price deflator, Dow Jones industrial average, money supply, prime rate, unemployment, federal funds rate, CPI, construction market condition, number of housing starts, number of building permits, construction spending, average hourly earnings, average weekly hours, 
and employment rate in construction and energy market condition (crude oil price) were the indicators. Sang et al. [18] assessed the impact of GDP, CPI, Korean composite stock price index, currency exchange rate, certificate of deposit interest rates, and corporate bond yields during insolvency of the Korean Construction Companies. Alfouzana and Khalafallah [40] identified the high cost of construction cost in Riyadh, Saudi Arabia, as a result of increase in oil prices, large demand for construction materials and labour due to government projects for housing, high demand for schools, hospitals, housing, low supply of housing, rapid rise in population growth, manipulation and monopoly of suppliers of construction materials, lack of trained labour, absence of the government in monitoring prices, corruption in monitoring government projects, existence of black market, high inflation rate, and exportation of construction materials outside of Saudi Arabia.

Heng et al. [41] in developing construction price prediction model considered national income, population, unemployment rate, and interest rate as the main variables. Ashuri and Shahandashti [42] considered the relationship between construction cost index and exogenous economic indicators such as CPI, federal funds rate, unemployment rate, prime rate, money supply, PPI, GDP, and GDP-implicit price deflator. Kim et al. [43] used the current ratio of liquidity ratio, debt ratio for leverage ratio, gross national income, index of liquidity, exchange rate, interest, and CPI as variables in analyzing the relationship between Korean financial crisis, the Korean construction industry, and the fluctuations of variables. Salama [44] in establishing a relationship between economic performance and cost of standard designs for educational buildings concluded that exchange rate and interest rate were the main indicators influencing the cost in Egypt.

Feng et al. [45] determined a relationship between exogenous variables and housing market cycle in China, and the factors considered were house prices, GDP, urban population at the end of year, per capita disposable income, fixed asset investment, consumer price index, loans of financial institutions, and average construction cost of completed residential. In Taiwan, money supply, CPI, PPI, unemployment, GDP, national consumption expenditure, and debt-to-GDP ratio were the indicators that influenced the forecast sale of large development and construction firms [46]. GDP, interest rate, property prices, and prime rate were identified as lead indicators in assessing the relationship between housing finance and variables in Hong Kong [47]. Padilla [48] also identified oil prices, exchange rate, employment levels, and interest rate as the main determinants for housing prices in Canada. Nwuba [49] concluded that inflation was the main cause of high cost of housing construction in Nigeria. Price fluctuation, inflation and exchange rate were identified as global exogenous factors that affected cost performance of the Mozambique construction industry [50]. Akintoye et al. [51] concluded that unemployment level, construction output, industrial production, and ratio of price to cost indices in manufacturing were the lead indicators of construction prices. Building cost index and GDP constitute coincident indicators. Nominal interest rate, inflation rate, real interest rate, all share index, and money supply produced inconclusive results. BaffoeBonnie [52] also established that stock of houses sold, housing prices, mortgage rates, consumer price index, employment growth, and money supply as indicators affecting housing prices and stock of house in the United Kingdom. Akintoye and Skitmore [53] identified unemployment level, real interest rate, manufacturing profitability, number of registered construction firms, building cost index, construction productivity, and construction work stoppages as the leading indicators in analyzing cost of construction. The review also considered some research papers relating to the construction industry in Ghana.

Danso and Obeng-Ahenkora [54] also considered crude oil prices, energy cost, local taxes and charges, cost of fuel and energy supply, high running cost, high prices of raw materials, cost of transportation, and cost of labour as the major determinants of price increase of building materials and recommended further research to determine the control measures of increases in prices of building materials. OtengAbayie and Dramani [55] advocated that contractors should focus on mitigating exchange rate risk in long-term projects and recommended for the publication and use of reliable building cost indices. Kissi et al. [56] identified major economic indicators that influence the forecast of tender price indices in buildings as composite CPI, PPI, currency exchange rate, GDP, and interest rate and suggested the need for critical examination of the extent of economic impact on pricing of building contracts. Amoateng and Osei [57] considered currency exchange rate, CPI, and the general economic conditions as the major exogenous factors influence tendering in public institutions. Amoah-Mensah [58] in developing local price adjustment factor for the building industry in West Africa considered exchange rate and changes in price of crude oil as major factors. Mensah et al. [59] concluded that lending rate, inflation, employment, and government expenditure were the main indicators affecting the performance of the industry. Bediako et al. [60] concluded that inflation rate, monetary policy rate, and exchange rate were the indicators that influenced the performance of cement prices determination in the Ghanaian construction industry. Asare et al. [61] analyzed cost trends in construction and concluded that inflation, price increases, and increase in import duties were some of the variables affecting cost. Adobor [62] considered exchange rate, inflation in terms of CPI, and crude oil prices in developing framework for construction cost indices in Ghana. The main objective was to identify exogenous factors affecting the construction, and the review indicated that GDP, exchange rate, inflation, interest rate, CPI, unemployment, employment, cost of crude oil, and PPI money supply were some of the common factors as indicated in Table 1.

\section{Methods of the Study}

This study was based on a comprehensive literature review on only relevant past empirical studies on the influence of exogenous economic factors. Literature review is commonly used in construction management research as a methodology 
TABLE 1: Identified exogenous economic factors.

\begin{tabular}{|c|c|c|}
\hline Item & Exogenous economic variables & References \\
\hline 1 & GDP & {$[16-18,24,25,27,28,30,31,34-39,42,45-47,56]$} \\
\hline 2 & Inflation & {$[16,23,24,26,27,31,32,36-40,49,59-62]$} \\
\hline 3 & Exchange rate & {$[18,23,25-27,33,43,48,55-58,60,62-64]$} \\
\hline 4 & Interest rate & {$[18,29,33,34,36,38,41,43,47-49,56,63]$} \\
\hline 5 & Consumer price index & {$[17,18,42,43,45,46,52,55-57,62]$} \\
\hline 6 & Unemployment & {$[17,22,24,34,39,41,42,46,51,53]$} \\
\hline 7 & Employment & {$[16,17,25,35-37,48,52,59]$} \\
\hline 8 & Cost of crude oil & {$[18,25,26,40,48,54,57,62]$} \\
\hline 9 & Monetary policy rate (prime rate) & {$[25,26,28,32,39,47,59,60]$} \\
\hline 10 & Real houses prices & {$[22,25,45,47,52]$} \\
\hline 11 & Money supply & {$[17,42,46,52]$} \\
\hline 12 & National revenue & {$[16,41,43,45]$} \\
\hline 13 & Demand for building/raw material & {$[17,32,40,54]$} \\
\hline 14 & Producer price index & {$[25,42,46,56]$} \\
\hline 15 & Public debt & {$[27,43,45,46]$} \\
\hline 16 & Housing statistics & {$[17,22,39,52]$} \\
\hline 17 & Taxation & {$[36,54,61]$} \\
\hline 18 & National expenditure & {$[16,46,59]$} \\
\hline 19 & Construction productivity & {$[25,51,53]$} \\
\hline 20 & Labour cost & {$[25,40,54]$} \\
\hline 21 & Cost of fuel & {$[17,29,54]$} \\
\hline 22 & Net importation & {$[27,29,38]$} \\
\hline 23 & Manufacturing profitability & {$[51,53]$} \\
\hline 24 & Building cost index & {$[53,55]$} \\
\hline 25 & Cost of construction & {$[37,54]$} \\
\hline 26 & Loan & {$[36,45]$} \\
\hline 27 & GDP-implicit deflator & {$[17,42]$} \\
\hline 28 & Capital goods prices & {$[16,25,26]$} \\
\hline 29 & Balance of payment & {$[27,35]$} \\
\hline 30 & Fixed assets & {$[27,45]$} \\
\hline 31 & Investor confidence/trade openness & {$[25,31]$} \\
\hline 32 & Net personnel saving & {$[27,31]$} \\
\hline 33 & Energy prices & {$[25,54]$} \\
\hline 34 & Net exportation & {$[27,40]$} \\
\hline 35 & Building permit/consent & {$[17,25]$} \\
\hline 36 & Black market & {$[40]$} \\
\hline 37 & Price monitoring and corruption & {$[40]$} \\
\hline 38 & Domestic demand for infrastructure & {$[40]$} \\
\hline 39 & Industrial production & {$[51]$} \\
\hline 40 & Number of registered construction firms & {$[53]$} \\
\hline 41 & Cost of transportation & {$[54]$} \\
\hline 42 & Corporate bond & {$[18]$} \\
\hline 43 & Mortgage rate & {$[52]$} \\
\hline 44 & Political regime & {$[38]$} \\
\hline 45 & Percentage of debt financing & {$[37]$} \\
\hline 46 & Foreign direct investment & {$[35]$} \\
\hline 47 & Forestry and animal husbandry & {$[30]$} \\
\hline 48 & Total retail sales of social consumer goods & {$[30]$} \\
\hline 49 & Industrial added value & {$[30]$} \\
\hline 50 & Agricultural added value & {$[30]$} \\
\hline 51 & Cost of production & {$[29]$} \\
\hline 52 & Public finance & {$[27]$} \\
\hline 53 & Private investment & {$[27]$} \\
\hline 54 & External reserve & {$[27]$} \\
\hline 55 & Net migration & {$[25]$} \\
\hline 56 & Fiscal policies & {$[25]$} \\
\hline 57 & Real personnel income & {$[22]$} \\
\hline 58 & Real personnel expenditure & {$[22]$} \\
\hline 59 & Homeownership & {$[22]$} \\
\hline
\end{tabular}


for advancing knowledge on specific topics [65-67]. This study adopted a three-stage approach as used by Ke et al. [68] cited by $\mathrm{Yu}$ et al. [69].

In the first stage, a systematic desktop search was conducted under the title, abstract, and keyword ("T/A/K") field of the Scopus search engine. This database was selected because it has been used widely for literature review studies in construction management, and also most of the research papers in the field of management, engineering, business, accounting, and construction are archived in Scopus $[65,70,71]$. The Scopus search engine is effective and efficient to conduct a literature review. It covers a wide range of literature in different areas in comparison with the Web of Science, Google Scholar, and PubMed [69, 72].

The following suited search keywords were used: "changes in exogenous (macroeconomic) factors indicators," "effects of exogenous economic indicators" and "Construction industry." Yu et al. [69], Darko et al. [65], Deng and Smyth [73], and Xue et al. [74] have applied keywords search to select papers and journals for review studies. The current study search was limited to exogenous economic factors and the construction industry. Fifty peer reviewed journals were selected for the study. The study realized that not all the identified papers presented empirical arguments about the impact of changes in exogenous economic indicators. Some of the papers just mentioned some of the search keywords in their title or abstract. Also, when compared with other related studies including Yu et al. [69] who used 26 papers as well as Osei-Kyei and Chan [70] who used 27 papers, the sample size of 50 could be considered satisfactory and reasonable to draw meaningful conclusions. The papers were subjected to qualitative content analysis.

\section{Discussions}

3.1. Exogenous Economic Factors Influencing Construction Industry. The motivation for this study was to identify exogenous economic indicators that have an effect on the performance of the construction industry. The study was a qualitative study of reviewing research articles on the subject under consideration. Fifty research works, including research articles, conference papers, and postgraduate dissertations were reviewed. The data were obtained from Scopus search engine, Web of Science, Google Scholar, and PubMed [69, 72]. Most of the reviewed works were on Ghana and the rest of the world with the aim of identifying exogenous economic factors influencing construction industry. The journals were on construction materials, mortgage, and real estate housing as well as the general cost of construction. The identified exogenous economic factors are as indicated in Table 1. Fiftynine exogenous indicators were identified. The most common exogenous economic factors were GDP, inflation, interest rate, consumer price index, exchange rate, unemployment, employment, crude oil price, producer price index, money supply, population, real houses prices, labour cost, and monetary policy. At least one of these common factors were identified in each of the research articles reviewed.

The review also identified some exogenous factors that were peculiar to specific countries. Mohsen [17] established
Dow Jones Industrial average and federal fund rate as factors influencing highway construction cost and energy market in the United States of America Alfouzana and Khalafallah [40] identified the existence of black market, price monitoring and corruption as contributing factors to cost escalation in Riyadh. In relation to specific exogenous factors, Sang et al. [18] also concluded that the Korean composite stock index as among the factors during the insolvency of the nation's construction industry. Ling et al. [30] also identified agricultural added value, forestry and animal husbandry, and total retail sales of social consumer goods. Studies relating to Ghana also established similar exogenous factors as stated above. This gives indications that researchers, policy makers, and players in the construction industry should focus on the impact of exogenous economy on the construction industry as advocated by Oteng-Abayie and Dramani [55]. None of the papers reviewed were specific on the real impact of these factors on the construction industry. This provides an opportunity for research particularly in developing economies like Ghana, where most of these factors are not stable and also political conditions have impact on these factors [16]. The review also did not identify any article proposing measures to control or mitigate the impact of these factors. Again policy makers should ensure that, during project lifecycle, there are measures to address the impact of these exogenous economic factors. The challenge of black market (illegal trading) is common in developing economies which leads loss of revenue to the state [40]. Therefore, it is important for policy makers to ensure that regulatory policies are in place to minimize the effect of illegal trading.

\section{Conclusion and Recommendations}

Various studies across the globe and specifically on Ghana have identified exogenous economic factors through different research methods. However, this study is the first study to conduct comprehensive literature review on the subject under consideration in the Ghanaian construction industry research study. With the aim of identifying exogenous economic factors influencing the construction industry through qualitative literature review, 59 such factors were identified and the most prevailing ones were GDP, inflation, interest rate, consumer price index, exchange rate, unemployment, employment, crude oil price, producer price index, money supply, population, real houses prices, labour cost, and monetary policy.

The study also identified some factors that were specific to some countries such as the existence of black market (illegal trading) and corruption in the construction in Riyadh. The study recommends further research on how illegal trading can affect the construction industry, and also further study is recommended to establish the strategies to mitigate the effects of exogenous economic factors.

The study also presents information to the policy makers on exogenous economic factors that need to be considered during planning, budgeting, and implementation of project lifecycle. Consultants and contractors are also provided with information on economic factors that should be of concern during project estimation and tendering and try to develop 
measures to mitigate the implications of these factors. Also, as most of these factors are usually not stable in developing economy like Ghana as concluded by Amo-Yartey [16] and Durdyev et al. [14], it provides opportunity for contractors to be very professional in executing projects in order to avoid contractual disputes, but rather, be able to compensate for any claims.

As with any research work, this study has a number of limitations since it was limited to comprehensive literature review; this provides direction for future research in a more detail qualitative and quantitative approaches to establish the main exogenous economic factors and their real impact on the construction industry. This study is an aspect of a broader Ph.D. research work, and this study was limited to qualitative literature review to identify exogenous economic factors. The next phase will be a quantitative study to establish the main influential exogenous factors and their real implications on the construction industry.

\section{Conflicts of Interest}

The authors declare that they have no conflicts of interest.

\section{Acknowledgments}

The authors wish to acknowledge the contributions of Miss Deborah Ama Duker in search for references.

\section{References}

[1] D. Agyapong, "Micro, Small and medium enterprises' activities, income level and poverty reduction in Ghana-a synthesis of related literature," International Journal of Business and Management, vol. 5, no. 12, 2010.

[2] D. W. Thwala, A. M. Ajagbe, I. W. Enegbuma, A. A. Bilau, and C. S. Long, "Sudanese Small and medium sized construction firms: an empirical survey of job turnover," Journal of Basic and Applied Scientific Research, vol. 2, no. 8, pp. 7414-7420, 2012.

[3] S. K. Amoah and A. K. Amoah, "The role of Small and medium enterprises (SMEs) to employment in Ghana," International Journal of Business and Economics Research, vol. 7, no. 5, pp. 151-157, 2018.

[4] G. Ofori, Developing the Construction in Ghana: The Case for a Central Agency, National University of Singapore, Singapore, 2012.

[5] Z. Abd-Hamid, N. A. Azizan, and S. Sorooshian, "Predictors for the success and survival of entrepreneurs in the construction industry," International Journal of Engineering Business Management, vol. 7, p. 12, 2015.

[6] B. M. Pulka, B. A. Ramli, and S. M. Bakar, "Conceptual framework on Small and medium enterprises performance in a turbulent environment," Sahel Analyst: Journal Of Management Sciences, vol. 15, no. 8, 2017.

[7] G. Acheampong, "Small and medium-scale enterprise (SME) survival in Ghana: a social network theory perspective," This thesis is submitted to the University of Ghana, Legon in Partial fulfillment of the requirement for the Award of Doctor of Philosophy Marketing Degree, University of Ghana, Accra, Ghana, 2015.

[8] T. M. Alimo, "The experiences of successful small business owners in Ghana," Doctoral Study submitted in partial fulfillment of the requirements for the Degree of Doctor of Business Administration, Walden University, College of Management and Technology, Minneapolis, MN, USA, 2015.

[9] T. Barnes, "Success factors for minority small business sustainability," Doctoral Study submitted in partial fulfillment of the requirements for the Degree of Doctor of Business Administration, Walden University, Minneapolis, MN, USA, 2019.

[10] N. J. Galawe, Endogenous and exogenous risk factors in the success of South African small medium enterprises, A thesissubmitted to the Faculty of Commerce, Law and Management,University of the Witwatersrand, Johannesburg, SouthAfrica, in fulfilment of the requirements for the degree of Doctor of Philosophy (Ph.D.) University of the Witwatersrand, Johanesburg, South Africa, 2017.

[11] P. F. Catalão, O. C. Cruz, and M. J. Sarmento, "Exogenous determinants of cost deviations and overruns in local infrastructure projects," Construction Management and Economics, vol. 37, no. 12, pp. 697-711, 2019.

[12] Z. Isik, D. Arditi, I. Dilmen, and M. Talat Birgonul, “The role of exogenous factors in the strategic performance of construction companies," Engineering, Construction and Architectural Management, vol. 17, no. 2, pp. 119-134, 2010.

[13] E. Prijon and L. Prijon, "The impact of exogenous factors on business elite's formation: comparing societies," Journal of Universal Excellence, vol. 4, no. 2, pp. A12-A36, 2015.

[14] S. Durdyev, M. Omarov, S. Ismail, and M. Lim, "Significant contributors to cost overruns in construction projects of Cambodia," Cogent Engineering, vol. 4, no. 1, 2017.

[15] B. Bok, D. Caratelli, D. Giannone, A. Sorbonne, and A. Tambalotti, "Macroeconomic nowcasting and forecasting with big data," Federal Reserve Bank of New York Staff Reports, Staff Report No. 830, The New York Fed's Public, New York, 2017.

[16] C. Amo-Yartey, Improving Fiscal Management in Ghana: The Role of Fiscal Policy Rules, IEA Monograph No 37, The Institute of Economic Affairs Ghana, Accra, Ghana, 2014.

[17] S. Mohsen, "Analysis of the temporal relationships between highway construction cost and indicators representing macroeconomic, and construction and energy market conditions," in Proceedings of the Construction Research Congress, Atlanta, Georgia, May 2014.

[18] J. Sang, H. Nam-Hyuk, K. Ju-Hyung, and K. Jae-Jun, "Impacts of macroeconomic fluctuations on insolvency: case of Korean construction companies," Journal of Management in Engineering, vol. 30, no. 5, Article ID 5014009, 2013.

[19] F. A. Halim, M. R. Malim, Z. Derasit, R. M. Rani, and S. S. Rashid, The Impact of Macroeconomic Variables on SMEs in Malaysia, Faculty of Computer \& Mathematical Sciences, Universiti Teknologi MARA, Shah Alam, Malaysia, 2017.

[20] S. Keswani and B. Wadhwa, "Effect of macroeconomic variables on stock market: a conceptual study," International Journal of Management, IT and Engineering, vol. 7, no. 10, 2017.

[21] A. L. Honorée, Y.-C. T. Morgan, and M. Krenn, "Heights of privilege: economic and cultural determinants of skyscraper height across the world," International Journal of Construction Management, pp. 1-14, 2018.

[22] A. J. Fieldhouse, K. Mertens, and M. O. Ravn, “The macroeconomic effects of government asset purchases: evidence from postwar U.S. Housing credit policy," The Quarterly Journal of Economics, vol. 133, no. 3, pp. 1503-1560, 2018. 
[23] A. Rauzana, "Uncertainty variables on cost estimation in project construction," IOSR Journal of Business and Management, vol. 20, no. 1, pp. 80-86, 2018.

[24] T. Asie, O. Lela, and Tamar, "Determining and predicting correlation of macroeconomic indicators on credit risk caused by overdue credit," Banks and Bank Systems, vol. 13, no. 3, pp. 114-119, 2018.

[25] I. Zhao, J. Mbachu, and N. Domingo, Exploratory Factors Influencing Building Development Costs in New Zealand, School of Engineering and Advanced Technology, Massey University, Auckland, New Zealand, 2017.

[26] Public Works Department and Construction Industry Development Board, The Drivers of the Cost of Public Sector Construction; Assessment and Recommendations, Republic of South Africa, 2017.

[27] M. M. Kembe and A. A. Onoja, "Cluster Analysis of macroeconomic indices," Journal of Statistics and Mathematical Sciences, vol. 3, no. 1, 2017.

[28] L. J. Wei, A. Z. H. Shukor, and M. H. Jamaluddin, "Investigation on standardization of modal space by ratio for MDOF micro-macro bilateral tele operation control system," Modern Applied Science, vol. 10, no. 11, 2016.

[29] A. S. Mansur, A. R. Abdul Hamid, and N. A. Yusof, "Rising trend in construction cost and housing price," Journal of Advanced Research in Business and Management Studies, vol. 3, no. 1, pp. 94-104, 2016.

[30] L. Ling, F. Li, and L. Cao, "Analyzing the relationship between urban macroeconomic development and transport infrastructure system based on neural network," in Lecture Notes in Electrical Engineering, vol. 419, Springer, Singapore, Construction, institutions and economic growth in SubSaharan Afric, 2018.

[31] P. Alagidede and J. Odei Mensah, "Construction, institutions and economic growth in Sub-Saharan Africa," in ERSA Working Paper 622, Economic Research Southern Africa (ERSA), National Treasury of South Africa, Pretoria, South Africa, 2016.

[32] J. U. Kalu, Z. Gyang, U. G. Aliagha, A. Buang, and I. J. Onuoha, "Monetary policy and its price stabilization effects on the prices of building materials," Mediterranean Journal of Social Sciences, vol. 6, no. 4, 2015.

[33] T. F. Adegbembo and O. Adeniyi, "Evaluating the effect of macroeconomic indicators on building materials prices," in Proceedings of the 2nd Research Conference-Recon2, The Nigerian Institute of Quantity Surveyors, Lagos, Nigeria, September 2015.

[34] C. Y. T. Denise, T. Y. Mau, and S. N. W. Tan, The Changes of Housing Price and its Relationship with the Macroeconomic Factors in the United States, Universiti Tunku Abdul Rahman, Faculty of Business and Finance Department of Finance, Kampar, Malaysia, 2015.

[35] O. Çoban, E. Ustundag, and A. Çoban, "The structural analysis of construction sector of Turkey and its effect on the selected macroeconomic indicators," Copernican Journal of Finance and Accounting, vol. 4, no. 1, pp. 27-44, 2015.

[36] T. Panagiotidis and P. Panagiotis, On the Macroeconomic Determinants of the Housing Market in Greece: A VECM Approach, GreeSE-Hellenic Observatory Papers on Greece and Southeast Europe 88, Hellenic Observatory, LSE, London, UK, 2015.

[37] J. W. Gathuru, "The effect of macroeconomic variables on the value of real estates supplied in Kenya," A Research Project submitted in partial fulfillment of the requirements for the award of the Degree of Master of Science in Finance, School of Business, and University Of Nairobi, Nairobi, Kenya, 2014.

[38] O. Oghenekevw, O. Olusola, and U. S. Chukwudi, "An assessment of the impact of inflation on construction material prices in Nigeria," PM World Journal, vol. 3, no. 4, 2014.

[39] M. Bełej and R. Cellmer, "The effect of macroeconomic factors on changes in real estate prices-response and interaction," Oeconomia, vol. 13, no. 2, pp. 5-16, 2014.

[40] S. A. Alfouzana and A. Khalafallah, "Housing and Construction Cost Escalation: Causes and Effects in Riyadh," in Proceedings of the Construction Research Congress 2014, Atlanta, Georgia, May 2014.

[41] J. Heng, Y. Xu, and C. Liu, "Construction price prediction using vector error correction models," Journal of Construction Engineering and Management, vol. 139, no. 11, 2013.

[42] B. Ashuri and S. M. Shahandashti, "Quantifying the relationship between construction cost index (CCI) and macroeconomic factors in the United States," in Proceedings of the 48th ASC Annual International Conference, Birmingham, UK, April 2012.

[43] S. Kim, S. Lee, and J. Kim, "Relationship between the financial crisis of Korean construction firms and macroeconomic fluctuations," Engineering, Construction and Architectural Management, vol. 18, no. 4, pp. 407-422, 2011.

[44] A. M. Salama, "The relationship between the performance of the economy and the costing of building projects: a case study of school buildings in Egypt," A dissertation submitted to the Graduate Faculty in partial fulfillment of the requirements for the Degree of Doctor of Philosophy in Construction Management Heriot-Watt University, School of Built Environment, Edinburgh, UK, 2011.

[45] L. Feng, W. Lu, W. Hu, and K. Liu, "Macroeconomic factors and housing market cycle: an empirical analysis using national and city level data in China," in Proceedings of the Conference on Web Based Business Management, Chengdu, China, September 2010.

[46] H. L. Chen, "Using financial and macroeconomic indicators to forecast sales of large development and construction firms," The Journal of Real Estate Finance and Economics, vol. 40, no. 3, pp. 310-331, 2010.

[47] S. Gerlach, W. Peng, and C. Shu, "Macroeconomic conditions and banking performance in Hong Kong SAR: a panel data study," in Investigating the Relationship between the Financial and Real Economy, BIS Papers Chapters, Bank for International Settlements, Ed., vol. 22, pp. 481-497, Bank for International Settlements, Basel, Switzerland, 2005.

[48] A. M. Padilla, "The effects of oil prices and other economic indicators on housing prices in Calgary," Canada submitted to the Department of Architecture in partial fulfillment of the requirements for the Degree of Master of Science in Real Estate Development, Massachusetts Institute of Technology, Cambridge, MA, USA, 2005.

[49] C. Nwuba, An Analysis of Housing Construction Cost Trends in Nigeria 1986-2002, Nigeria Institute of Quantity Surveyors, Lagos, Nigeria, 2004.

[50] D. Baloi and D. F. Price, "Evaluation of global risk factors affecting cost performance in Mozambique," in Proceedings of 2001 RICS Construction and Building Conference (COBRA 2001), pp. 74-86, Glasgow, UK, September 2001.

[51] A. Akintoye, P. Bowen, and C. Hardcastle, "Macro-economic leading indicators of construction contract prices," Construction Management and Economics, vol. 16, no. 2, pp. 159-175, 1998. 
[52] J. Baffoe-Bonnie, "The dynamic impact of macroeconomic aggregates on housing prices and stock of houses: a national and regional analysis," The Journal of Real Estate Finance and Economics, vol. 17, no. 2, pp. 179-197, 1998.

[53] A. Akintoye and M. Skitmore, "Macro models of UK construction contract prices," Civil Engineering Systems, vol. 10, no. 4, pp. 279-299, 1993.

[54] H. Danso and N. K. Obeng-Ahenkora, "Major determinants of prices increase of building materials on Ghanaian construction market," Open Journal of Civil Engineering, vol. 8, no. 2, pp. 142-154, 2018.

[55] F. E. Oteng-Abayie and J. B. Dramani, "Time-frequency domain causality of prime building cost and macroeconomic indicators in Ghana: implications for project selection," Construction Management and Economics, vol. 37, no. 5, pp. 243-256, 2018.

[56] E. Kissi, T. Adjei-Kumi, P. Amoah, and B. E. Boateng, "Identifying key economic indicators influencing tender price index prediction in the building industry: a case study of Ghana," International Journal of Construction Management, vol. 19, no. 2, pp. 106-112, 2017.

[57] A. Amoateng and K. Osei, "External market conditions that affect cost of tendering in public institutions: evidence from Ghana," British Journal of Economics, Management and Trade, vol. 17, no. 3, pp. 1-12, 2017.

[58] K. Amoa-Mensah, Building Estimating Manual for West Africa, Construction Exchange, Kumasi, Ghana, 3rd edition, 2016.

[59] F. Mensah, G. Ofori-Abebrese, and R. Pickson, "Empirical analysis of the relationship between industrial performance and macroeconomic factors in Ghana," British Journal of Economics, Management and Trade, vol. 13, no. 4, pp. 1-11, 2016.

[60] M. Bediako, C. D. Adobor, E. O. Amankwah, K. Nyako, and C. K. Kankam, "Maximizing the sustainability of cement utilization in building projects through the use of greener materials," Journal of Engineering, vol. 2016, Article ID 1375493, 6 pages, 2016.

[61] E. K. Asare, W. Gyadu-Asiedu, and A. Fokuo-Kusi, "An analysis of construction cost trends in Ghana," in Proceedings of the 7th Annual International Applied Research Conference, Theme: Technology and Innovation; The Bedrock for Sustainable Development, Koforidua, Ghana, July 2014.

[62] D. C. Adobor, "Framework for development of construction cost indices using unit rate," M.Sc. unpublished thesis presented to the Department of Building Technology, Kwame Nkrumah University of Science and Technology, Kumasi, Ghana, 2014.

[63] M. Salama, A. Kaka, and C. Leishman, "The relationshipbetween the performance of the economy and the cost ofconstruction of educational buildings in Egypt: a preliminarystudy," in Proceedings of the 21st Annual ARCOM Conference, F. Khosrowshahi, Ed., vol. 2, pp. 731-740, SOAS, University of London. Association of Researchers in Construction Management, London, UK, September 2005.

[64] K. Amoa-Mensah, Building Estimating Manual for West African Construction Practice, Parcom, Kumasi, Ghana, 2nd edition, 1996.

[65] A. Darko, C. Zhang, and A. P. C. Chan, "Drivers for green building: a review of empirical studies," Habitat International, vol. 60 , pp. 34-49, 2017.

[66] Z. Li, G. Q. Shen, and X. Xue, "Critical review of the research on the management of prefabricated construction," Habitat International, vol. 43, pp. 240-249, 2014.
[67] C. C. Tsai and M. Lydia Wen, "Research and trends in science education from 1998 to 2002: a content analysis of publication in selected journals," International Journal of Science Education, vol. 27, no. 1, pp. 3-14, 2005.

[68] Y. Ke, S. Wang, A. P. Chan, and E. Cheung, "Research trend of public-private partnership in construction journals," Journal of Construction Engineering and Management, vol. 135, no. 10, pp. 1076-1086, 2009.

[69] Y. Yu, R. Osei-Kyei, A. P. C. Chan, and I. Martek, "Review of social responsibility factors for sustainable development in public-private partnerships," Sustainable Development, vol. 26, no. 3, pp. 1-10, 2018.

[70] R. Osei-Kyei and A. P. C. Chan, "Review of studies on the critical success factors for public-private partnership (PPP) projects from 1990 to 2013," International Journal of Project Management, vol. 33, no. 6, pp. 1335-1346, 2015.

[71] Y. Hong and D. W. M. Chan, "Research trend of joint ventures in construction: a two-decade taxonomic review," Journal of Facilities Management, vol. 12, no. 2, pp. 118-141, 2014.

[72] M. E. Falagas, E. I. Pitsouni, G. A. Malietzis, and G. Pappas, "Comparison of PubMed, Scopus, web of science, and Google scholar: strengths and weaknesses," The FASEB Journal, vol. 22, no. 2, pp. 338-342, 2008.

[73] F. Deng and H. Smyth, "Contingency-based approach to firm performance in construction: critical review of empirical research," Journal of Construction Engineering and Management, vol. 139, no. 10, Article ID 4013004, 2013.

[74] X. Xue, Q. Shen, and Z. Ren, "Critical review of collaborative working in construction projects: business environment and human behaviours," Journal of Management in Engineering, vol. 26, no. 4, pp. 196-208, 2010. 


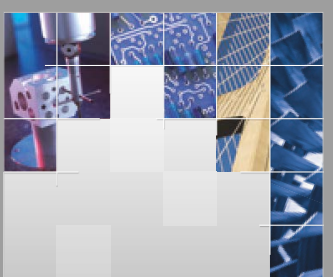

\section{Enfincering}
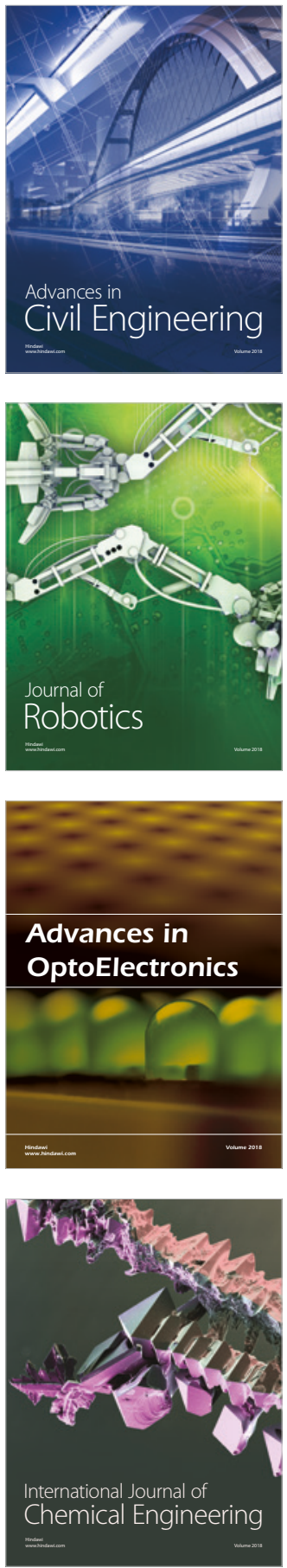

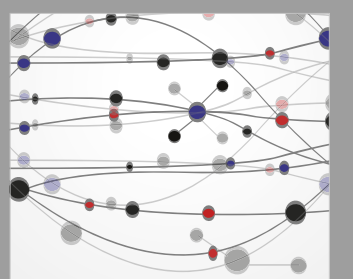

\section{Rotating \\ Machinery}

The Scientific World Journal

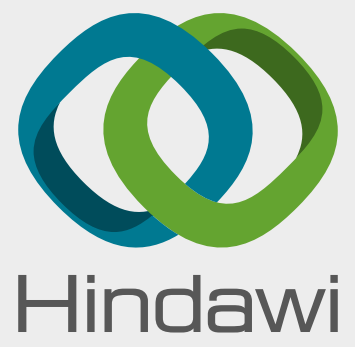

Submit your manuscripts at

www.hindawi.com
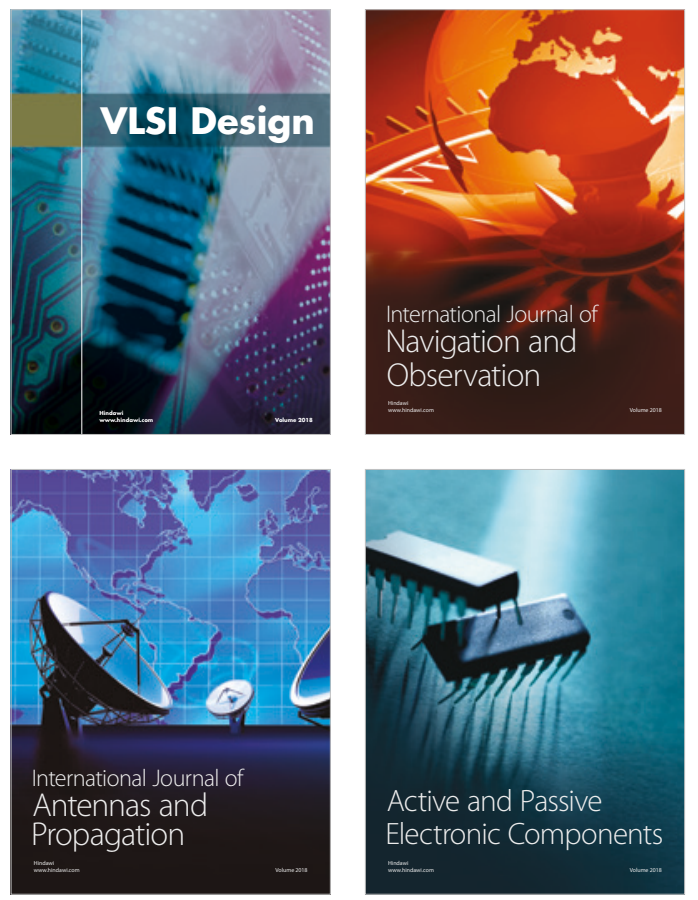
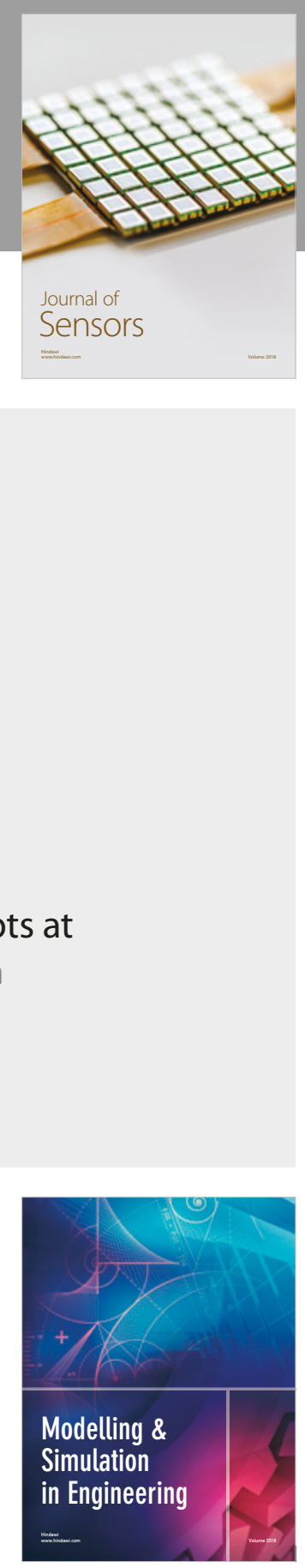

\section{Advances \\ Multimedia}
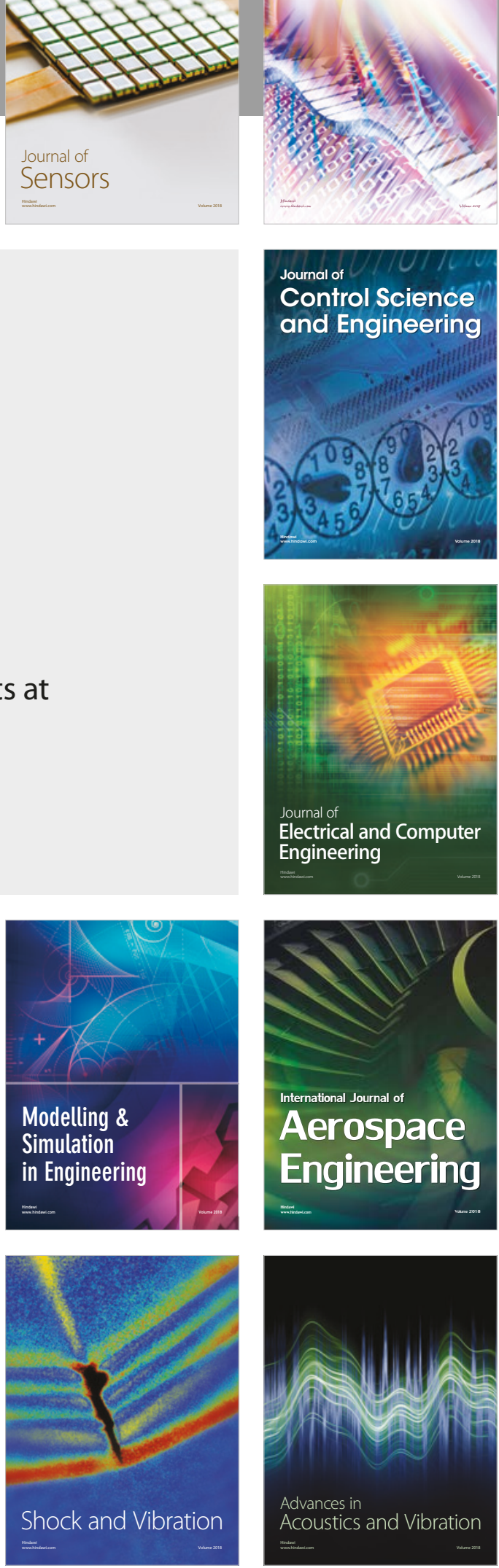